\title{
INTERNALISASI NILAI KARAKTER DEMOKRATIS-RELIGIUS MELALUI PENGEMBANGAN MATA KULIAH KULIAH TAFSIR TEMATIK TERINTEGRASI CIVIC EDUCATION
}

\author{
'M. Naelul Mubarok \\ 'Institut PTIQ Jakarta \\ naelulmubarok@ptiq.ac.id
}

Naskah diterima: 25 Agustus 2021, direvisi: 30 November 2021, disetujui: 10 desember 2021

\section{Abstrak}

Penelitian ini bertujuan untuk mengetahui Internalisasi nilai karakter demokratis religious melalui pengembangan mata kuliah tafsir tematik terintegrasi mata kuliah civic education. Jenis penelitian merupakan penelitian lapangan (field research). Adapun pendekatan yang dugunakan adalah pendekatan kualitatif. Penelitian dilakukan di Institut PTIQ Jakarta. hasil penelitian menunjukkan bahwa internalisasi nilai dapat dilakukan dengan menggunakan strategi integrasi mata kuliah yang memiliki topik-topik kajian yang memiliki relevansi satu sama lain. Internalisasi nilai demokratis religious bisa diupayakan melalui kedua mata kliah tersebut. Adapun pengimplementasian dilakukan dengan tahap perencanaa yang meliputi perencanaa Tujuan capaian pembelajaran tiap mata kuliah, Menentukan tema atau topik yang akan dibahas pembelajaran, menyusun RPS. Pada tahap pelaksanaan melalui pengajaran mata kuliah meliputi: Presentasi, diskusi, telaah relevansi konsep yang dikembangkan dalam masing-masing mata kuliah, mengkompromikan perdebatan ilmiah melalui pendekatan tafsirr tematik.

Kata Kunci : Internalisasi Nilai, Demokratis-Religius, Civic Education, Tafsir Tematik 


\section{PENDAHULUAN}

Bangsa Indonesia adalah salah satu bangsa yang menerapkan sistem demokrasi. Setiap warga negara didalamnya diharuskan untuk menjunjung tinggi nilai-nilai demokrasi tersebut. Nilai-nilai demokrasi dapat diraih manakala kesadaran akan pentingnya berdemokrassi telah tertananm dalam diri stiap warga. Namun pada kenyataanya demokrasi di Indonesia seringkali diciderai oleh ulah kelompok-kelompok tertentu yang mengangap bahwa sistem demokrasi yang ada di negeri ini tidak sesuai dengan unsur-unsur adat, budaya, agama, kesukuan dan komponen komponen SARA yang lain. Di setiap kontestasi politik, saat tiba musim pemilu, pilpres hampir selalu ada gesekan antar golongan baik golongan yang mengatasnamakan agama ataupun golongan yang mengatasnamakan demokrasi. Hal ini tentu dapat meracuni cara berpikir generasi muda yang pada dasarnya sedang berada pada fase pencarian jati diri dan sedang dalam keadaan cara berpikir yang kritis dan pragmatis pada konsep-konsep tertentu yang mereka yakini kebenarannya. Hal ini tentu menggugah para penyelenggara pendidikan baik dari kalangan praktisi maupun dosen dan para pengajar lainnya untuk meredam gejolak yang sering terjadi tersebut melalui berbagai ide dan gagasannya. Masalah bertambah manakala muncul diantara mereka yang religious namun kurang demokratis ataupun sebaliknya demokratis namun tidak religious.

Dewasa ini kesadaran untuk membentuk pribadi yang cerdas dan berbudi pekerti luhur semakin terasa. Hal tersebut dibuktikan dengan maraknya diskursus tentang masalah karakter bangsa. Baik karakter untuk generasi mudanya maupun generasi yang kini sedang menjadi bagiaan dari pengelolaan bangsa ini. Banyak upaya yang dilakukan oleh pemerintah dalam upaya mewujudkan cita-ita luhru tersebut, mulai dari mendesain kurikulum yang bermuatan karakter sampai pengembangan kebijakankebijakan yang secara berkala mengalami pembaharuan demi terciptanya progersifitas. Begitupun lembaga pendidikan berupaya untuk berpartisipasi dalam mengimplementasikan pengajaran nilainilai karakter melalui berbagai desain inovasi dan kreatifitasnya yang dituangkan dalam metode strategi pengajaran di tiap mata kuliahnya. Terdapat beberapa penelitian yang membahas tentang bagaimana seharusnya perguruann tinggi berinovasi dalam menyelenggarakan 
praktek pendidikan karakter bagi mahasiswa diantaranya adalah: penelitian yang dilakukan oleh (Chanifah, 2015) mengungkapkan bahwa perlu ada desain tersendiri untuk mengajarkan nilai-nilai karakter melalu mata kuliah sehingga terdapat program pengajaran nilai-nilai yang holistik dan integratif diantara mata kuliah. Penelitian yang dilakukan oleh (Asyanti, 2012), dalam penelitiannnya mengungkapkan bahwa dalam upaya meningkatkan pendidikan karakter di perguruan tinggi diperlukan adanya kebijakan yang bersifat non-kurikulum. Untuk mewujudkan pembentukan karakter (Schwartz, 2000) menyatakan universitas atau perguruan tinggi baik yang berbasis religious ataupun perguran tinggi berbasis umum, dapat mamanfaatkan kekuatan kurikulum sebagai sarana pembentukan pemikiran dan penerapan nilai-niali karakter.

Menyikapi tantangan tersebut Perguruan Tinggi llmu Al-Quran Jakarta mencoba mendesain pengajaran mata kuliah yang penting untuk mencetak genarasi yang demokratis dan sekaligus religious. Melalui desain integrasi mata kuliah diharapkan internalisasi nilai-nilai demokratis religious melalui pengajaran di kelas dapat terwujud. Lalu bagaimanakah internalisasi nilai karakter demokratis religious melalui integrasi mata kuliah tafsir tematik dengan Civik Education.

\section{METODE PENELITIAN}

Penelitian ini merupakan penelitian Lapangan (fields research) melalui pendekatan deskriptif kualitatif. Tempat penelitian adalah Institut PTIQ Jakarta dengan objek penelitian mata kuliah yang diintegrasikan dan subjek penelitiannya adalah mahasiswa dan dosen. Data diperoleh melalui teknik observasi dan wawancara serta kajian litelatur yang mendalam sebagai penguat konsep. Sumber data primer berasal dari hasil pengamatan dan wawancara di lapangan, adapun data sekunder berasal dari buku-buku, jurnal, artikel ilmiah dan lain sebagainya yang mendukung untuk sumber kajian penelitian. Data diolah dan dianalisis melalui serangkaian proses triangulasi data dan kemudian paparkan secara deskriptif.

\section{PEMBAHASAN DAN HASIL} PENELITIAN

\section{Internalisasi Nilai karakter}

Nilai dipandang serta diyakini sebagai suatu hal yang berharga berkaitan dengan baik dan buruk. Sedangkan keyakinan akan nilai tersebut dibentuk oleh pengalaman hidup seharihari (Darmiyati, 2001), (Azizah, 2014) 
mengemukakan bahwa nilai bersifat abstrak, posisi nilai berada di belakang fakta, melahirkan tindakan, melekat dalam moral seseorang, muncul sebagai ujung proses psikologis, dan berkembang ke arah yang lebih kompleks. Dari semua definisi yang telah diabarkan terkait nilai, dapat disimpulkan bahwa nilai adalah segala hal yang berhubungan dengan tingkah laku manusia mengenai baik atau buruk yang diukur oleh agama, tradisi, etika, moral, dan kebudayaan yang berlaku dalam masyarakat. Pendidikan karakter merupakan proses memberikan tuntunan kepada siswa dalam tujuannya menjadi manusia yang mampu mengktifkan olahpikir,olah raga, olah karsa dan rasanya sebagai manusia yang sempurna (Samani, 2013).

Internalisasi nilai karakter pada dasarnya merupakan suatu upaya menanamakan nilai-nilai karakter ke dalam diri seseorang. Internalisasi adalah tindakan yang dilakukan oleh seseorang melalui praktek dengan kesadaran. Tanpa adanya paksaan, definisi ini berarti bahwa internalisasi dilakukan secara sadar yang akan membentuk adat atau kebiasaan dalam diri seseorang. Pengertian internalisasi adalah pembelajaran selama hidup di dunia, yang dilakukan oleh seseorang kepada masyarakat atau kelompok- kelompok sosial. (Suharman, 2017) Pembelajaran ini sendiri berupa penyerapan aturan dalam masyarakat, nilai, dan norma (Lisnawaty W Badu :2021).

Dari penjelasan tersebut dapat kita artikan bahwa Internalisasi pada hakikatnya adalah suatu proses memasukkan/menjadikan masuk sesuatu (dalam hal adalah nilai karakter) ke dalam diri individu. Internalisasi adalah suatu proses dimana seseorang belajar, kemudian dapat mengaplikasikan suatu hal tersebut dalam kegiatan sehari-hari. Di dalam lingkungan pendidikan baik di sekolah maupun perguruan tinggi penginternalisasian nilai-nilai karakter dapat dilakukan dengan cara memodifiksi kurikulum yang diterapkan. (Muhaimin, 2012) menjelaskan bahwa dalam lingkup pendidikan penginternalisasian nilai melalui tahapan-tahapan berikut ini:

1) Tahap Transformasi Nilai, tahapan pertama ini orang tua bertugas memberikan informasi nilai-nilai yang dianggap bak dan kurang baik melalui aktivitas komunikasi verbal semata. Transformasi nilai dapat terjadi di dalam maupun di luar kelas baik bersifat sengaja maupun secara spontan sebagai bentuk komunikasi 
antar guru dan siswa di lingkungan belajar.

2) Tahap Transaksi Nilai, pada tahap ini terjadi komunikasi dua arah atau komunikasi yang bersifat timbal balik. Orang tua tidak lagi mengajarkan kepada anak melalui pengajaran melakinkan terjadi interaksi yang mengharapkan adanya respon dari anak berupa pendapat, pandangan, komentar ataupun penilaian siswa terhadap suatu fenomena nilai tertentu. Nilai nilai tersebut bisa berasal dari lingkungan komunitasnya berupa tingkah laku seluruh warga sekolah sehingga muncul respon untuk mengamalkan nilai-nilai tersebut atau tidak.

3) Tahap Transinternalisasi Nilai, pada tahapan ini terjadi hubungan timbal balik nilai dan satu sama lain antar orang tua dan anak muncul dalam bentuk karakteristik yang dapat saling memberikan stimulus nilai.

$$
\text { Lickona (1991) sebagaimana }
$$

dikutip oleh (Susanti, 2013) mengemukakan bahwa praktek pendidikan karakter berhubungan dengan segala usaha yang dapat dilakukan untuk mempengaruhi karakter siswa. Kemudian lebih lanjut Lickona berpandangan bahwa pengertian pendidikan karakter adalah suatu usaha yang disengaja untuk membantu seseorang sehingga ia dapat memahami, memperhatikan, dan melakukan nilai-nilai etika yang sebenarnya.

Dalam salah satu bukunya yang berjudul 100 Ways to Enhance Values and Morality in Schools and Youth Settings (Kirschenbaum, 1995), Howard Kirschenbaum menguraikan seratus cara untuk dapat meningkatkan nilai dan moralitas (akhlak mulia) di sekolah yang bisa dikelompokkan ke dalam lima metode, yaitu: 1) inculcating values and morality (penanaman nilai-nilai dan moralitas); 2) modeling values and morality (pemodelan nilai-nilai dan moralitas); 3) facilitating values and morality (memfasilitasi nilai-nilai dan moralitas); 4) skills for value development and moral literacy (keterampilan untuk pengembangan nilai dan literasi moral; dan 5) developing a values education program (mengembangkan program pendidikan nilai).

\section{Karakter Demokratis-Religius}

Setiap warga negara Indonesia perlu menjunjung tinggi sikap demokratis dan religius. Demokratis berkaitan dengan karakter seseorang yang mengedepankan hak-hak dan kewajiban sebagai warga negara sesuai dengan landasan hokum dan dasar 
negara yang ada. Sedangkan religious berhubungan dengan karakteristik seseorang yang senantiasa menjadikan agama sebagai cara pandang hidupnya, yang meliputi seluruh bentuk tuturkata, sikap hidup dan perbuatannya. Dengan demikian karakter demokratis-religius merupakan penggabungan dari dua karakteristik tersebut. Yaitu berkaitan dengan karakteristik seseorang sebagai warga negara yang menjunjung tinggi hak dan kewajiban manusia dengan menjadikan cara pandang bangsa dan agamanya sebagai pedoman hidupnya. Orang yang demokratis senantiasa mengedepankan sikap-sikap; musyawarah untuk mencapai mufakat, saling menghargai dan menghormati, terdapat payung hukum yang jelas untuk melindungi hak dan kewajiban masyarakat, pemilihan umum, lembaga yang bisa menyalurkan aspirasi masyarakat, menyalurkan aspirasi dengan cara yang damai, bebas yang bertanggung jawab, menjunjung tinggi kepentingan negara di banding kepentingan individu dan kelompok, taat kepada konstitusi hokum yang berlaku, rasional, jujur dan adil.

Nilai-nilai demokrasi dalam Islam sebenarnya telah banyak dicontohkan oleh Nabi Muhammad Saw selama masa hidupnya. Baik dalam berinteraksi dengan umat maupun dengan system kekuasaan negara yang pada saat itu berlangsung. Peristiwa meletakkan batu hajar aswad menggunakan sorban dimana masingmasing kabilah/suku mendapat kesempatan memegang sorban, peristiwa munculnya perjanjian hudaibiyah dan piagam madinah merupakan bentuk dari sikap-sikap demokratis yang dulu pernah diajarkan oleh baginda Nabi Muhammad Saw. Keberhasilan Nabi dalam mengemban amanat bangsa Arab tersebut merupakan bukti bahwa sikap demokratis yang religious bisa diupayakan dan bisa menjadi sikap karakter yang memiliki keunikan tersendiri bagi warga muslin di Indonessia

\section{Integrasi Mata kuliah}

Integrasi mata kuliah artinya menggabungkan satu atau beberapa mata kuliah untuk menjabarkan topictopik perkuliahan. Mata kuliah dicari relevansinya dengan mata kuliah yang lain. Pengintegrasian mata kuliah adalah sebagai upaya untuk memberikan pemahaman secara holistic kepada mahasiswa melalui berbagai sudut pandang. Pengintegrasian mata kuliah harus mengedepankan aspek keterkaitan antar mata kuliah yang satu dngan mata kuliah lainnya yang dianggap sejalan dan relevan atau memiliki keterkaitan. 
Integrasi mata kuliah bertujuan agar konsep-konsep yang diajarkan lebih dapat diterima dan memiiki keluasan materi yang semakin baik, memiliki dasar-dasar yang sangat kuat, baik secara filosofis, normatif, juridis maupun historis. Dasar filosofis menyangkut argumen atau konsepsi filosofis yang menunjukkan bahwa pada dasarnya semua ilmu itu sederajat dan saling membutuhkan dalam rangka mencapai tujuan-tujuan kemanusiaan yang lebih tinggi. Landasan filosofis bisa mencakup tiga ranah dalam filsafat ilmu, yaitu, ontologis (eksistensi dan hierarki pengetahuan), epistemologis (sumber-sumber dan instrumen pemerolehan ilmu), dan aksiologi (nilai dan penerapan pengetahuan). Dasar normatif dalam integrasi ilmu menyangkut dasar-dasar keagamaan (teks-teks agama) bagi perlunya upaya re-integrasi ilmu atau menghilangkan dikotomi antara ilmu-ilmu agama dan ilmu-ilmu lainnya. Sumber bagi dasar normatif ini mencakup Alquran dan Hadis serta produkproduk penafsiran para ulama terhadap kedua sumber ajaran Islam tersebut yang berkaitan dengan ilmu pengetahuan dalam Islam. Integrasi ilmu tidak dimaksudkan sebagai upaya "Islamisasi pengetahuan" (Islamization of Knowledge) dalam pengertian yang dimaksudkan oleh ilmuan seperti Muhammad Naquib al-Attas, lsmail Raji' al- Faruqi dan kolega-koleganya. Istilah ini telah digunakan dalam filsafat Islam kontemporer yang menguat di paruh kedua abad ke-20 untuk merujuk pada upaya mendamaikan atau merekonsiliasikan Islam dan modernitas, khususnya mencari cara untuk mengadopsi metode ilmiah dengan cara yang konsisten dengan norma-norma etika Islam

lntegrasi mata kuliah sangat baik dilakukan pada mata kuliah yang memiliki topik pembicaraan yang sangat luas dan memiliki sensitifitas yang tinggi. Integrasi mata kuliah bagi lembaga dapat memudahkan lembaga pendidikan untuk memecahkan permasalah secara spesifik atas permasalahan yang dikaji. Hal tersebut tentu dapat mendatangkan keuntungan berupa temuan riset-riset terbaru yang bisa dipertanggung jawabkan unsur keilmiahannya. Integrasi mata kuliah dapat mengefisienkan waktu, tenaga dan juga biaya. Dengan integrasi dua mata kulaih sekaligus dapat digabungkan dalam satu kelas belajar.

Internalisasi Nilai melalui Integrasi Mata kuliah Tafsir Tematik dan Civic Education 
Upaya Internalisasi Nilai karakter demokratis religious mealui integrasi mata kuliah di Institut PTIQ merupakan hasil dari diskusi panjang dalam pembahasan kurikulum Institut. Institusi mempertimbangkan bahwa perlu adanya suatu kolaborasi mata kuliah yang dapat mengarahkan mahasiswa menuju cara pandang yang bijak dalam menyikapi isu tentang demokrasi. Sehingga dirasa. Sebagai institusi yang bercorak keagamaan dengan nilai-nilai Al-Quran dan Hadis sebagai landasannya maka Institut PTIQ menetapkan bahwa Mata Civic Education diintegrasikan dengn Tafsir tematik.

Dalam mata kuliah civic education mahasiswa diajarkan tentang pendidikan menjadi warga negara yang baik, dan mampu berkarya untuk Bangsa di berbagai bidang keahlian yang dimilikinya. Dalam mata kuliah civic education juga menekankan pentingnya menghargai, bertoleransi, menjunjung hak-hak kemanusian, yang merupakan ruh dari demokrasi. Pendidikan kewargaan (civic education) menjadi Mata Kuliah Wajib Umum MKWU untuk memberikan bekal ketika mereka hidup bermasyarakat sehingga mereka dapat menentukan sikap dan tingkah lakunya yang sesuai dengan normanorma kehidupan mayarakat. Mahasiswa sangat ditekankan untuk dapat menyelesaikan bergabai persoalan yang terjadi di dalam kehidupan bermayarakat melalui berbagai pendekatan sesuai dengan bidang yang mereka kuasai. Dalam kaitannya dengan Instutut PTIQ yang basis pendidikannnya adalah keagamaan maka sangat ditekankan bagi mahasisawa untuk dapat menyelesaaikan probelmatika kehidupan bersosial berbangsa, bernegara dan beragama dengan panduan wahyu.

Mata Kuliah Tafsir tematik merupakan mata kuliah yang berdiskusi konsep-konsep di dalam Islam yang terjadi di dalam kehidupan ummat manusia sehari-hari di berbagai aspek kehidupannya baik politik, ekonomi, sosial, budaya, kesehatan, pendidikan, sains dan lain sebagainya. Tematik artinya setiap topic yang akan dibahas dalam mata kuliah disesuaikan dengan tema-tema actual yang membutuhkan diskursus dan pemecahan masalah. Fenomea-fenomena yang terjadi di masyarakat tersebut dipecahkan dengan mengkaji konsep-konsep yang terdapat di dalam Al-Quran dan Hadis. Hal ini mengingat bahwa $\mathrm{Al}-\mathrm{Quran}$ dan hadist adalah sumber dari segala seumber konsep yang ada untuk kehidupan umat Islam. Dalam pengimplementasiannya Internalisasi nilai dilakukan melalui 
beberapa tahapan yaitu, Perencanaan, Pelaksanan, dan Evaluasi

$$
\text { Pada tahap perencanaan, }
$$

beberapa hal yang direncanakan adalah;

1) Perencanaa Tujuan capaian pembelajaran tiap mata kuliah dalam hal ini adalah mata kuliah Civic Education dan Tafsir Tematik, pada tahap ini dirancang CP (capaian Pembelajaran) Baik yang meliputi Capaian dalam ranah, pengetahuan, sikap dan keterampilan yang diharapkan setelah mengikuti mata kuliah tersebut. 2) Mangumpulkan topik-topik aktual yang berkaitan dengan pendidikan kewargaan secara tematik dan begitu pula dengan mata kuliah tafsir agar memepersiapkan konsep dan landasan yang dapat dijadikan sebagai penguat argument melalui telaah tafsir-tafsir yang telah dibahas secara ilmiah 3) Merencanakan pendekatan strategi yang akan dilakukan dalam pembelajaran. 4) merumuskan rencana-rencana kedalam RPS.

Pada tahap pelaksanaan, proses penginternalisasian nilai-nilai karakter melalui pengajaran tafsir tematik terintegrasi civis education dilakukan melalui beberapa aktifitas: 1) presentasi, pada kegiatan ini konsep-konsep dipaparkan oleh pemakalah, yaitu mahasiswa yang bertugas. Makalah harus disusun dengan mengkaji konsep- konsep umum yang dipadukan dengan konsep-konsep agama dimana basis konsepnya adalah 1-Quran. 2) Diskusi, pada kegiatan ini mahasisw saling bertukar gagasan tentang pokok bahasan yang telah dipresentasikan dengan memberikan pandangan, komentar ataupun melontarkan kritik dan saran dengan dasar-dasar pengetahuan ilmiah. 3). Meluruskan pandangan yang telah ada dengan mengadopsi dalil-dalil ayat serta penafsiran-penafsiran dari para ahli sehingga ditemukan pandangan yang dianggap lebih cocok untuk diterima.

Tahap selanjutnya yaitu tahap Evaluasi. Pada tahap ini mahasiswa melakukan serangkaian aktifitas 1) refleksi diri, yaitu aktivitas menilai sejauh mana dirinya telah menyerap dan mengamalkan nilai-nilai karakter demokratis-religius dalam kehidupan sehari-hari. 2) merekonstruksi cara pandang yang menyimpang dengan melakukan penelaahan terhadap ayatayat Al-Quran dan Hadist untuk memperkuat pembentukan konsep diri tentang sikap demokratis yang diwarnai dengan unsur religiusitas. 3) Menyusun projek yang berkaitan dengan penyelesaian masalah melalui skema penelitian dan pengabdian kepada masyarakat. 4) Menjalin kerjasama dengan para pakar untuk mencari 
kesepahaman dalam kaitannya dengan sikap demokratis yang juga religious.

\section{KESIMPULAN}

Penginternalisasian karakter demokratis religious di Institut PTIQ Jakarta diimplementasikan melalui pengajaran Tafrir tematik terintegerasi dengan mata pelajaran Civic Education. Dua mata kuliah tersebut memiliki relevansi dalam mendiskusikan topictopik yang berhubungan dengan penyelesaian maslah-masalah demokrasi di negara ini yang dikombinasikan dengan cara pandang agama Islam melalui pengkajian konsep-konsep secara umum dan konsep-konsep berdasarkan Al-Quran dan Hadist. Internalisasi nilai demokratis religious bisa diupayakan melalui kedua mata kliah tersebut. Adapun pengimplementasian dilakukan dengan tahap perencanaa yang meliputi perencanaa Tujuan capaian pembelajaran tiap mata kuliah, Menentukan tema atau topik yang akan dibahas pembelajaran, menyusun RPS. Pada tahap pelaksanaan melalui pengajaran mata kuliah meliputi: Presentasi, diskusi, telaah relevansi konsep yang dikembangkan dalam masing-masing mata kuliah, mengkompromikan perdebatan ilmiah melalui pendekatan tafsirr tematik. Pada tahap perencanaan meliputi, perencanaan visi musi dan tujuan melalui CPL, perencanaan materi ajar, dan perencanaan pendekatan strategis pengajaran, perumusan ke dalam RPS (Rencana Pengajaran Semester),. Tahap pelaksanaan meliputi: presentasi makalah, diskusi permasalahan inti, meluruskan pandangan melalui konsep yang didasari oleh pemikiran ilmiah disertai dalil dalil pendukung, dan Tahap selanjutnya Evaluasi yang terdiri atas, refleksi diri, merekonstruksi cara pandang yang menyimpang, Menyusun projek yang berkaitan dengan prnyelesaian masalah, Menjalin kerjasama dengan para pakar

\section{DAFTAR PUSTAKA}

Asyanti, S. (2012). Pendidikan Karakter di Perguruan Tinggi: Sudah Terlambatkah? Prosiding Seminar Nasional Psikologi Islami , 284291.

Azizah, Nur. (2014). Perilaku Moral dan Religiusitas siswa Berlatar Belakang pendidikan Umum dan Agama. Jurnal Psikologi, I(2), 3545.

Chanifah, N. (2015). Desain Pendidikann Karakter di Perguruan Tinggi Umum, Seminar Nasional Riset Inovatif III. 
Darmiyati, Z. (2001). Pendekatan Pendidikan Nilai Secara Komprehensip Sebagai Suatu Alternatif Pembentukan Akhlak Bangsa. Yogyakarta: Makalah Disampaikan Pada Seminar Terbatas Pusat Penelitian Uny Tanggal II Juni 20ol, 185-186.

Kirschenbaum, H. (1995). 100 Ways To Enhance Values And Morality In Schools And Youth Settings. Massachusetts : Allyn \& Bacon.

Lisnawaty W Badu (2021) Perlindungan Hak-Hak Konstitusional Masyarakat Adat di Kabupaten Boalemo dalam Penerapan Sanksi Adat. Juurnal Konstitusi Volume 18, (I) hl.220-239 https://doi.org/10.31078/jk18110

Muhaimin. (2012). Paradigma Pendidikan Islam, Upaya Mengefektifkan Pendidikan Islam Di Sekolah. Bandung : PT. Remaja Rosda Karya.

Samani, M. \& H. (2013). Konsep Dan Model Pendidikan Karakter. Bandung : Remaja Posdakarya.

Schwartz, A]. (2000). It's Not to Late to Teach College Student about Values. The Chronicle of Higher Education., 46(40), A68.
Suharman. (2017). Faktor Determinan Akhlak Remaja. Jurnal Conciencia, 18(2), 70-98.

Susanti, Rosa. (2013). Penerapan Pendidikan Karakter di kalangan Mahasiswa. Jurnal Al-Ta'lim, (6), 480-487. 
p-ISSN 2685-8401 e-ISSN 2685-7502

(Halaman sengaja dikosongkan) 